\title{
Bad math in Linnaeus' Philosophia botanica
}

\author{
Running head: Bad math in Linnaeus' Philosophia botanica
}

János Podani ${ }^{1}$, András Szilágyi ${ }^{2}$

1 Department of Plant Systematics, Ecology and Theoretical Biology, Institute of Biology, Eötvös University and MTA-MTM-ELTE Ecology Research Group, Pázmány P. s 1.C, H-1055 Budapest, Hungary. Corresponding author. Email: podani@ludens.elte.hu, Telephone: +3613812293

2 Department of Plant Systematics, Ecology and Theoretical Biology, Institute of Biology, Eötvös University and MTA-ELTE Theoretical Biology and Evolutionary Ecology Research Group, Budapest, Hungary.

Footnote: This paper is dedicated to the memory of the father-in-law of the first author, the biologist and educator Gy. Kontra (1925-2007). A decade ago, he surprised J. P. by a gift, an original copy of Philosophia Botanica, its Berlin (1780) edition.

Acknowledgments. The authors are grateful to the editor, S. Müller-Wille for his detailed comments which greatly improved the manuscript, and the anoymous referee for the constructive criticism. We thank Veronika Kulin for her help with latin translations, Partícia Dérer for assistance with the Russian language and Enrico Feoli for translating some text in Italian. 
"Botanica innititur fixis Generibus"

Linnaeus 1751, p. 139.

Abstract. In Philosophia Botanica (1751), Carolus Linnaeus (1707-1778)

presented a calculation of the number of plant genera that may be distinguished based on his taxonomic concepts. In order to derive that number, he relied upon the organs of fructification, which represent the flower and the fruit, by selecting over thirty elements from them, and then assuming that each could vary by four dimensions. However, while Linnaeus was good in counting stamens and pistils, he and many of his followers who edited or translated Philosophia botanica were less careful, basing their calculations of the number of possible genera on flawed assumptions, or even introducing basic arithmetic errors. Furthermore, although mathematics was quite advanced in the eighteenth century, the gap between combinatorial and botanical thinking was too deep, preventing Linnaeus to seek a reasonable solution to the problem he raised. The authors demonstrate this by a historical analysis of 15 editions of Philosophia Botanica, plus many references to it, and conclude that the desired number almost always appeared in error during the past 265 years. The German botanist J. G. Gleditsch (1714-1786) was the most successful with respect to Linnaeus' original intention. Elementary mathematics demonstrates that if Linnaeus' assumptions were taken seriously, then the possible number of genera would be astronomical. The practice he followed in Genera Plantarum (1754) shows, however, that the 
fructification dimensions served as a universal set for Linnaeus from which he chose only the relevant ones for describing a particular genus empirically. Based on the corrections and modifications implemented in reworked editions, we suggest an evolutionary network for the historical and modern versions or translations of Philosophia Botanica.

Keywords: Elementary combinatorics, Fructification, Genus concept, Gleditsch, Text evolution, Willdenow.

\section{Introduction}

Carolus Linnaeus (Carl von Linné, 1707-1778), the "father of taxonomy", has been considered the most influential naturalist of his times, whose suggestions and views still persist in contemporary biology through the use of binominal nomenclature and the hierarchical system of ranks. In fact, the ideas of no other biologist from the eighteenth century have the privilege to have survived that long. Linnaeus recognized five levels in the taxonomic hierarchy of the plant kingdom: varieties, species, genera, orders and classes. Genera were considered the most natural of all by him, since - as the above motto illustrates - they represented a fixed basis of botanical classification (Larson 1971).

In his famous book, Philosophia Botanica in qua explicantur fundamenta botanica cum definitionibus partium, exemplis terminorum, observationibus rariorum, adjectis figuris aeneis (henceforth abbreviated as $\mathrm{PhB}$ ), published first 
in 1751 in Stockholm (and simultaneously in Amsterdam), Linnaeus described a morphological system of plant parts by which genera were defined. He believed that a set of characters related to the reproductive organs of the plant, i.e. the flower and the fruit (collectively termed as fructification), provided a finite number of combinations, large enough to exceed the number of genera that were empirically known to exist at that time - thereby considering the use of other characters as a mistake for delimiting taxa of that rank. The biological, philosophical and theoretical aspects of Linnaeus' essentialism in his genus concept have been described, analyzed and debated thoroughly in the literature on Linnaeus's place in the history of biology (see e.g. Larson 1971, Stafleu 1971, Atran 1990, Ereshefsky 2004, Müller-Wille 2007).

However, there is an interesting point that mostly escaped the attention of historians, namely the mathematical correctness of Linnaeus' reasoning: some problems with arithmetics, the consistency of the numbers of relevant plant parts, the formula by which he calculated the number of genera that may be distinguished based on the selected characters, and the question of how these were changed in subsequent editions of the book. This paper is an attempt to reveal these issues, based on an extensive literature survey. Also, we hope to document some other facts that deepen our understanding of how Linnaeus' concepts were modified - sometimes haphazardly - by botanists at the turn of the nineteenth century. 


\section{A brief summary of Philosophia botanica}

Of the several books Linnaeus had written, $\mathrm{PhB}$ exerted probably the greatest impact upon the theory and practice of plant systematics in the eighteenthnineteenth century. As an early appreciation of this work, Pulteney (1805, p. 105) considered $\mathrm{PhB}$ "a most extraordinary and pre-eminent performance."Much more recently, Stearn $(1985$, p. 36$)$ recognized it as“...the first textbook of descriptive systematic botany and botanical Latin." $\mathrm{PhB}$ is based on Fundamenta Botanica (published in Amsterdam, 1736), which is a collection of 365 aphorisms arranged into 12 chapters, and printed on 36 pages. Using some of his subsequent books and lecture notes, Linnaeus greatly expanded the contents while maintaining the original structure, ending up with a considerably longer book with a total of 362 pages plus ten plates (Eddy 2010). It is therefore better to say that the book comprises 365 sections, rather than "aphorisms" as Linnaeus himself called them (Freer 2003), because the latter are today understood as short statements containing subjective views or observations of their authors ${ }^{1}$. The 1751 edition of $\mathrm{PhB}$ was the only one actually handled by Linnaeus; all subsequent printings were either unchanged or edited and translated by other botanists (Pulteney 1805). Unless otherwise noted, in this paper all mentions of chapters, sections and page numbers refer to the first edition. 
The first chapter is a historical account of important botanists of all times, while the second one provides a brief summary of plant classifications including two of his own, the sexual system and - the much less widely known arrangement of plants into 68 natural groups (“fragments" in Section 77, see Cain 1993).

Chapter 3 is devoted to the vegetative characteristics of plants, i.e. those related to the root, the stem and the leaf, whereas reproductive organs are described in the next chapter. The sexual behavior of plants is the subject matter of Chapter 5. The issue of selecting characters that are useful in establishing higher categories, including genera, is elaborated in Chapter 6, with the related nomenclatural rules being detailed in the next one. Linnaeus presents the laws for distinguishing species and varieties, respectively, in the next two chapters. The manner how synonyms are to be handled is the topic of Chapter 10. Many features of plant life, including phenological and ecological observations by the author, are summarized in Chapter 11. Finally, Chapter 12 outlines the many different ways plants can contribute to human welfare. The book is concluded with Memoranda, providing advice for the novice in botany, the plant collector, the gardener and the botanist traveler, and some short observations on the "metamorphosis" of plants.

\footnotetext{
${ }^{1}$ Eddy (2010) circumvented the problem by saying that Linnaeus used „three hundred and sixty-five aphoristic sections."
} 


\section{Relevant sections}

In the context of the present paper, sections of particular interest occur in the fourth and the sixth chapters. Chapter 4 (entitled Fructificatio $=$ fructification or fruiting-body) begins with Section 86 (with the same title as the chapter) in which Linnaeus proposes the use of seven parts (partes) of the temporary organs dedicated to the reproduction of plants ("Vegetabilium pars temporaria, Generationi dicata", see detail in Fig. 1.a). As said in Section 87, four of them (I-IV.) pertain to the flower (calyx, corolla, stamen and pistil [pistillum]) and three (V-VII.) to the fruit (pericarp [pericarpium], seed [semen] and the receptacle [receptaculum]). For each of these parts, Section 86 lists several items, numbered consecutively from 1 to 31 : seven for the calyx, two for the corolla, three for the stamen, three for the pistil, eight for the pericarp, three for the seed and five for the receptacle. ${ }^{2}$ No general term is associated with most items, except for the nectary (under corolla), the filament and the anther (under stamen), and the style (under pistil), each of which is explicitly addressed as a part (pars) of the respective main part. Thus, to simplify discussion, and for complicated reasons explained later, we will refer to all items generally and collectively as elements.

\footnotetext{
${ }^{2}$ In the corresponding aphorism of Fundamenta Botanica, Linnaeus lists 6 items for the calyx, 2 for the corolla, 2 for the stamen, 3 for the pistil, 3 for the pericarpium, 2 for the semen and 3 for the receptacle, giving a total of 21. A year later was published the first edition of Genera Plantarum eorumque characteres naturales secundum numerum, figuram, situm, \& proportionem omnium fructificationis partium (Leiden 1737) in which the Preface mentions 26 items distributed over the parts as follows: 6 for the calyx, 3 for the corolla, 2 for the stamen, 3 for the pistil, 7 for the pericarp, 2 for the seed and 3 for the receptacle (see Müller-Wille and Reeds 2007).
} 
Sections 92-93 outline very briefly that the "most natural structure" (naturalissima structura) of fructification can be described in terms of four principal dimensions (dimensiones) of the elements (Fig. 1.b). These are the number (numerus), shape (figura), proportion (proportio) and position (situs or locus). In Section 98, Linnaeus anticipates that genera will be distinguished by the "differing structure" (differens structura), i.e. on the basis of individual differences in "those parts that often differ in various plants." These differences are then elaborated in detail for each part of fructification, although - as we shall see - the 31 elements will not reappear one by one. Section 99 immediately provides an example: the calyx as a part is detailed in terms of eleven dimensions, with all the four principal dimensions included (Fig. 1.c). The perianth (element 1 ) is not mentioned explicitly, although we may assume that some dimensions refer to it. For the involucre (element 2) and the sheath (element 3), only the number of leaves is considered, while the remaining four elements that appeared in Section 86 under calyx are omitted here. Section 100 deals with the corolla, with all dimensions reflecting petal (element 8) characters, while the details for nectary (element 9) are postponed to Section 110. The number, shape, proportion and location of petals are discussed here, plus four other dimensions. Section 101 is more evenly organized: the filaments (element 10) differ in all the four principal dimensions, just like the anthers (element 11, although proportio is renamed to connectio), while pollen (element 
12) has only the number dimension. Section 102 explicitly states that the three elements belonging to it are indeed parts of the pistil. The ovary (element 13) is said to follow the "laws" (leges) of the pericarp, and is not detailed here. The style (element 14) has, among others, all the four principal dimensions, although proportio is replaced by length (longitudo). The stigma (element 15) has number, shape and length. Section 103 lists dimensions for the entire part of the pericarp, without details on the constituting elements that were numbered 16-23 in Section 86. Dimensions include number, shape and position, whereas proportio is replaced here by enclosure (inclusio). Seed properties are detailed in Section 104, with all dimensions, including the four principal dimensions related to seed proper (element 24). The nut (element 25) and propago ("seed of a moss", element 26) are not mentioned here. After this section, the receptacle part is expected to come - but only a few hints are given on the "receptacle of composite [flowers]" (elements 28-31) at the end of section 104, without mentioning the dimensions explicitly. The same is true for the nectary in Section 110 - shifted here from the discussion of the corolla in section 100.

Finally, in Chapter 6 (Characteres) only Section 167 deserves our attention, the one of primary concern in this paper. The aphorism introducing this section according to Freer's translation, reads: "Every characteristic feature ought to be elicited from the number, shape, relative size, and position of all the different parts of the fruit-body [omnium partium Fructificatio] (98-104)." The numbers 
refer to the sections we just discussed. Then follows a small summary table, listing first the seven main parts of fructification together with the number of elements included within each of these, their total being (" 38 "), and then the four principal dimensions. Below the table, Linnaeus multiplies the total number of elements with the number of dimensions, and the result is multiplied again by the number of elements producing the result of " 5736 " (Fig. 3.a). Thus, Linnaeus handles all elements in the same manner and with equal weight in the calculations. The final score was far greater than the number of genera recognized in Linnaeus' times - leading him to conclude that the fructification "suffices for at least 5736 genera: which could not ever exist" (London2003, p. 130; original latin in Fig. 3.a). Therefore, according to Linnaeus, it is mistaken to consider things other than those listed above the calculation in establishing plant genera. The value of 5736 may be interpreted as the upper limit (maximum) of the number of genera that can be defined based on the fructification characteristics considered most relevant by Linnaeus, whereas it is also plausible that he merely wanted to show that the 31 elements and the four dimensions were more than sufficient for distinguishing the known genera (Müller-Wille, pers. comm.). No matter which interpretation reflects his intention better, it is a fact that Linnaeus attempted to derive a concrete value for a maximum number of possible genera given his morphological distinctions, to 
which, for ease of reference within this paper, we shall refer as Linnaeus' number, abbreviated by $\boldsymbol{L}$.

\section{Material}

Thanks to the wide availability of internet resources, including the Biodiversity Heritage Library, Google Book Search and Internet Archive, we were able to examine 15 editions of $\mathrm{PhB}$ (Table 1) which included all historical versions scanned by different libraries. The bibliographies of Hulth (1907), Soulsby (1933) and Stafleu and Cowan (1981) also list a German edition (Augsburg, 1787), a Spanish version (Madrid, 1778) and a Russian edition (Saint Petersburg, 1800) $)^{3}$. However, these are not translations in the strictest sense but compilations from various sources, and do not contain the material we are comparing here. In most cases, PDF or DJVU files could be downloaded, occasionally with limited access; in which cases we were still able to extract the information necessary for the present survey (i.e. we could read all relevant sections). In addition, we had a chance to inspect the hard copies of two editions (Stockholm, 1751; Berlin, 1780) as well. The different editions will be referred to by abbreviations composed by the location and the date of publication, for example, "London1775".

\footnotetext{
${ }^{3}$ Linné, Carl von. 1787. Pflanzenphilosophie im Auszuge, nach Linné's Methode; Augsburg: Wolff; Linnaeo, C. 1778. Explicacion de la Filosofia y Fundamentos Botanicos. Madrid: Jardin Botanico (transl. A. Palau y Verdera); Linney, K. 1800. Filosofiya Botaniki. Sanktpeterburg: Akademii Nauk (transl. T. Smelovsky).
} 


\section{Results and discussion}

\section{Terminological issues}

To ensure unambiguous presentation of our results and observations, clarification of the somewhat chaotic terminology applied in the past 260 years to the character hierarchy of Linnaeus is in order. The basic unit is fructification, which splits unequivocally into the flower and the fruit. Also, there is general agreement that items at the next level are parts, four belonging to the flower and three to the fruit. In other words, calyx and the corolla and the stamen and the pistil comprise the flower, while the pericarp and the seed and the receptacle constitute the fruit.

At the next level, $\mathrm{PhB}$ is equivocal, as mentioned earlier already. In Chapter 4, the term "part" is restricted to items that are actually parts of main parts, whereas in Section 167 of Chapter 6, all items are counted equally as parts in the summary table. Ambiguity remains in most subsequent editions, including the French one (Paris1788) as well as Berlin1780, Berlin1790, and Madrid1792. The fact that the items listed for calyx, seed, pericarp and the receptacle are not parts - because they cannot co-occur in the same plant - was recognized by the translator H. Rose in London1775. He says, for example, that the "calyx comprehends the seven following species, viz. the perianthium, the involucrum, the amentum, the spadix, the gluma, the calyptra, and volva." For Lee (1788), 
calyx "has received different Appellations, according to the Circumstances with which it is attended." Seed, pericarp and the receptacle also have different appellations in this work. That is, the and logical operator does not apply to these four parts of fructification: the calyx is either perianth or involucre or amentum or spadix, and so on... In the recent literature, ambiguity is resolved by Larson (1971, pp. 76-78) who used the term kind for these structures, and suggested the collective term element for kinds and parts together. Atran (1987, 1990) and Andrietti and Generali (2002) took over the term element, a convention that we follow here as well. The distinction between kinds and parts is especially important when one wishes to derive $\mathbf{L}$ more exactly (see below).

The term dimension used by Linnaeus also underwent several changes in reeditions, translations and references. ${ }^{4}$ It remains in Paris1788, as well as in Section 94 of Berlin1790 and in Moscow1989 ("izmerenie" = dimension), but the word disappeared without replacement from Section 92 in London1775 and Berlin1780. Alternatives in later works include object (Lee 1788), aspect (Larson 1971, Kwa 2011), measurement (Oxford2003), and variable (Atran 1987, 1990, Ereshefsky 1997, 2004). We maintained the original word, dimension, because it happens to coincide quite well with our current mathematical understanding of the term.

\footnotetext{
${ }^{4}$ Even Linnaeus himself was inconsistent in this regard, because he used dimensions interchangeably with ,attributes, modes, mechanical principles, mechanical fundamentals" and - in Fundamenta botanica„diversities” (Cain 1994, p. 20).
} 
The character hierarchy is completed by states, i.e. the possible values a dimension can take (Fig. 2). For instance, the shape (as dimension) of the perianth (as a kind of the main part calyx) can have four distinguished states, namely globosus (spherical), clavatus (club-shaped), reflexus (reflected) and erectus (upright). We shall assume that the states for any dimension are mutually exclusive notwithstanding that Linnaeus knew that flowers can vary in their character states even on the same individual (Müller-Wille 2007).

Fructification: how many elements?

The small summary table on pp. 116-117 of the first edition of Philosophia botanica (Fig. 3a) indicates seven elements for the calyx, two for the corolla, three for the stamen, three for the pistil, eight for the pericarp, and four each for the seed and the receptacle. These numbers appear unchanged in most other editions of $\mathrm{PhB}$, as well as in relatively new references to it (e.g., Atran 1987, p. 261; Ereshefsky 1997, p. 496; 2004, p. 202, Andrietti and Generali 2002, p. 155). Upon reading the detailed description of the seven main parts (Stockholm1751, pp. 54-55), however, we find that seed in fact has three elements only (semen, nux and propago) while receptacle has five (receptaculum proprium, receptaculum commune, umbella, cyma and spadix). Thus, when compiling the small table, Linnaeus committed a simple mistake by increasing the number of elements for the seed on the account of the number of elements of the receptacle. 
There are only two editions in which this is not so. H. Rose in his English translation of $\mathrm{PhB}$ (London1775, p. 251) makes the correction by replacing the small table with continuous text saying "Of the seed three species, viz. semen, nux, propago. Of the receptacle five, viz. receptaculum proprium, receptaculum commune, umbella, cyma, spadix". C. L. Willdenow went much further on with editing: he replaced Linnaeus' original table by another in which the fructification has eight (rather than seven) main parts, the new one being nectarium as separated from the corolla (Berlin1790, p. 118; see Fig. 3d). However, three values of the small table are in conflict with Willdenow's detailed description of fructification (Berlin1790, pp. 54-57) in which corolla has only one element (rather than 2), nectarium has one (rather than 2) and seed also has one (rather than 4) - changes which obviously influence their sum as well.

The total number of elements (summa, denoted here by $n$ ) is thus another critical issue. If we examine the small summary table again, we find that Linnaeus put 38 as the sum, while the total number of relevant elements listed in Section 86 is only $31(=7+2+3+3+8+4+4)$ ! The difference is 7 , and we have the impression that Linnaeus added "VII", the number of main parts appearing on the top of the small table as well. In this way, he inadvertently introduced an error which persisted in many reprints, editions and translations until our times (Vienna1755, Vienna1763, Vienna1770, London1775, Paris1788, Madrid1792, Halle1809, 
Tournay1824, Moscow1989, Oxford2003). For example, F.-A. Quesné inserted "7" into the small table of the French edition (Fig.1b), perhaps for consistency with the other numbers. According to our survey, it was J. G. Gleditsch (Berlin1780) who first recognized and corrected Linnaeus' mistake appropriately, and modified the summa in the table to 31 (Fig. 3c). Two subsequent editions (Vienna1783, Geneva1787) were also correct in this regard. It is striking therefore that the value " 38 " survived in references to $\mathrm{PhB}$ until the end of the twentieth century (e.g. Svenson 1945, Larson 1971, Stafleu 1971, Roger 1981, Géczy 1982) and, although Atran (1987, p. 261) mentioned in a footnote that Linnaeus' summation was wrong, the total " 38 " appeared again in even more recent references to $\mathrm{PhB}$ (Hacker 1992, Bueno 1998, Kwa 2011).

Willdenow's (Berlin1790) small table is even worse in the arithmetical sense. It is not merely that the numbers given in the list of main parts and elements (his Section 89) and in the table (his Section 170), respectively, are inconsistent, as mentioned above already. The values that are actually given in the small table (Fig. 3d) yield a total of 35, rather than 33, indicating an unexplained arithmetic error. But the true summa is in fact 30 , as seen in the detailed list of elements on pp. 54-57 (his Section 89) of Willdenow's edition! It is worth noting, however, that this is due not to a simple removal of one element from Linnaeus' original list. For example, element 6 (calyptra, pertaining only to mosses) and element 7 (valva, the "calyx fungi") were deleted and the entire set of calyx descriptors 
was reworked to include elements that characterize flowers of seed plants only. Further changes include the move of nux from the seed part to the pericarp, removal of yet another moss character and the replacement of umbella and cyma by strobilus. Thus, the quite substantial changes implemented by Willdenow made the book more consistent with the morphology of flowering plants as we understand it today. As Stafleu and Cowan (1981) noted, this book "should be attributed to the editor."

Two editions, "studio Curtii Sprengel” (Halle1809, Tournay1824) represent a very different situation. In these, the summary table in Section 167 is the same as in Stockholm1751 (Fig. 3a) as mentioned above, while in Section 86 on fructification the total number of elements is indeed 38 ! But the numbers in the small table and in Section 86 have nothing to do with each other. In Halle1809 (pp. 97-102), the 38 elements are distributed over the seven main parts in the following manner: calyx 10, corolla 2, stamen 3, pistillum 3, pericarpium 16 , semen 2 and receptaculum 2. There are new elements, never mentioned in earlier editions, such as the indusium, a fern character appearing under calyx, and hymenaeum, a fungus character listed under the pericarp. The Tournay1824 edition maintains this categorization (pp. 93-98). If Sprengel's original intention was to increase the number of parts to 38 , for harmonization with Linnaeus' summa, then it is surprising that the scores in the table itself remained in error. 


\section{The total number of dimensions}

According to Linnaeus' suggestion, first the number of elements is multiplied by the number of dimensions that describe each element, to get $4 n$, which is therefore the total number of dimensions that can characterize a plant genus. For instance, the number of styles is one dimension, the shape of the style is another. The result of multiplication is 124 (for 31 elements) or 120 (for 30 elements) consequently all other values calculated with a summa of 38 or 33 are wrong.

This operation implies that every one of the 31 elements can be characterized in terms of all the four dimensions. In Linnaeus' discussion of fructification, however, we find that this is not the case, for several reasons. Certain dimensions cannot be logically defined for some elements (e.g., the proportion of style in Section 102). For many elements, Linnaeus did not specify the four dimensions at all in Sections 99-104. On the other hand, as we saw above, for a couple of elements there are more than four dimensions listed: e.g. 11 for the perianth of calyx including, for example, compositio, margo, apex and duratio (pp. 62-73), but these extra dimensions were considered irrelevant by Linnaeus in the circumscription of genera. All in all, as we could say now, 124 is a gross "overestimation" of the number of dimensions that could be meaningful in the context of describing a given genus. 
Naïve combinatorics - a damned number

In Section 167, Linnaeus wanted to get the number of possible combinations of fructification dimensions to derive $\mathbf{L}$, the maximum number of genera that may exist, assuming that two genera must differ in at least one principal dimension. Thus, species within a genus cannot differ in any of the 124 fructification dimensions and are allowed to do so in other dimensions of fructification and in vegetative parts. Linnaeus believed that calculation is a simple matter and, notwithstanding that the four dimensions did not apply to all elements, retained $4 n$ and - apparently -multiplied it by $n$ again to obtain the upper limit, that is 38 $\cdot 4 \cdot 38$, giving $\mathbf{L}=5736$ for him (see bottom of Fig. 3a). Actually, what he said quite vaguely was that "Let the procedure be changed according to the 38 parts, and let it be 5736" (Oxford2013, p. 130). The words "multiplied" and “multipliés" appeared first in London1775 and Paris1778, respectively.

Indeed, the mathematically correct result is 5776,40 higher than what Linnaeus calculated. Since the value of 5736 appeared twice, in two successive lines of the book (Fig. 3a), we can put forward the hypothesis that it was not a typographic error but Linnaeus' own mistake. Many editions of the book inherited this arithmetic error, including the second to fourth printing in Vienna. Scopoli (1786) refers to Linnaeus' work by mentioning 5736 as well. In Moscow1989, the value of 5736 remains in the text, but corrected in a comment 
by the translator, N. N. Zabinkovoy, at the end of the book. Modern reports that retained the erroneous value of 5736 include Vasilyeva and Stephenson (2008), Oittinen $(2007,2009)$ and a thesis by Čermáková (2013)

It was the English translator, H. Rose, who realized first that Linnaeus did not get the correct value of $\mathbf{L}$, and replaced 5736 by 5776 (London1775). The latter value appeared again in Paris1788 (Fig. 3b) and Madrid1792. One of these editions may have been the reference for Svenson (1945) and Stafleu (1971) who also mentioned 5776, potentially serving as a further source for Géczy (1982, p. 15), Foucault (2002, p. 154), Weinberger (2007) and Kwa (2011, p. 187) who repeated exactly this figure, just like two dissertations (Stemerding 1991, p. 52, Lara Filho 2006, p. 35). Larson (1971, p. 91) was a bit more careful by saying that "one hundred and fifty-two, which being again multiplied by the number of parts, provides over five thousand possible distinctions."

Gleditsch (Berlin1780), who used $n=31$ rather than 38, was better in arithmetics and derived first the correct value of $\mathbf{L}$ Linnaeus originally wanted to get: $31 \cdot 31 \cdot 4=3844$ (also in Vienna1783, Geneva1787). ${ }^{5}$ Referring to Geneva1787, Atran (1987, p. 261) was the first in modern times to call attention to the fact that Linnaeus did not multiply the values correctly. Ironically enough, however, Atran (1987, p. 303) reported accidentally yet another wrong number, 
that is 3884, which appeared again in Atran (1990, p. 171) and was taken over by Ereshefsky (2004, p. 202). This apparent misprint was corrected - without mentioning the error in the source reference - by Andrietti and Generali (2002, p. 155), the only recent work we were able to find with the correct value of 3844. One will never know if the error in the third digit has to do with the same position of the false digit in Linnaeus' calculations! The story could not be concluded better than with Willdenow's mistake (Berlin1790): after multiplying his own 33 by 4 , and then by 33 again, he got 4326 (Fig. 1d), although the correct result is 4356 - a mistaken third digit again. But, obviously, based on his true value of $n=30$, Willdenow's version of the upper limit for the number of genera should have been $4 \cdot 30^{2}=3600$.

That $\mathbf{L}$ is a damned number is not just a question of bad arithmetics, though. The real problem lies in fact in the logic of how Linnaeus' formula, $\mathbf{L}=4 n^{2}$ was developed. We might ask if there is any logic at all. As one can judge from his attitude towards theory, Linnaeus did not justify his decision that $4 n^{2}$ should be the limit. To our knowledge, no authors have ever attempted to figure out why $4 n$ was multiplied again by $n$, and the entire literature of the history of biology is silent about this issue. As the simplest explanation we can guess that, since he first knew 935 and finally 1343 plant genera (in the first and the last authored

\footnotetext{
${ }^{5}$ Nevertheless, in the text below the table the wrong value of 38 remained: ,ergo quater triginta octo" (see Fig. 3.c).
} 
editions of Genera Plantarum, ${ }^{6}$ Linnaeus wanted to select a number large enough to allow for future generic descriptions. The value of $n$ and its square might have appeared an "objective" choice for him, and he was probably satisfied with the result, but its rationale is unclear.

In fact, the meaning of $4 n^{2}$ cannot be explained by combinatorial thinking, and it is likely that Linnaeus had not the slightest idea of combinatorics. However, we can give a mathematically correct approximation to $\mathbf{L}$ based on the following considerations. We start from the assumption that there are 31 relevant elements (7, 8, 3 and 5 kinds distributed among the calyx, pericarp, seed and receptacle, respectively, and 2, 3 and 3 parts among the corolla, stamen, pistil, respectively, Fig. 2) and four dimensions for each, giving a total of $28+32+12+20=92$ dimensions for kinds and 32 for parts, each of which with two states. We assume further that character states are independent among parts, which is probably impossible biologically. Thus, the minimum number of distinct cases would be 2 $\cdot(28 \cdot 32 \cdot 12 \cdot 20) \cdot 2^{32} \approx 1.85 \cdot 10^{15}$, an extremely large number. As we have seen in the previous Section, however, Linnaeus' understanding of elements and dimensions is not consistent at all with this simple logic, and the actual number of dimensions is in fact much fewer than $92+32=124$, while the number of states exceeds two in most cases. By examining Sections 99-104 in which Linnaeus describes fructification in detail, therefore, we can derive a more

\footnotetext{
${ }^{6}$ Genera Plantarum had seven editions published in the lifetime of its author, the first - as said in
} 
reasonable estimation for Linnaeus' "magic" number. These, somewhat tedious calculations are presented in the Appendix and the result is ca. 4 magnitudes higher than the score obtained above.

Now, it is worth examining briefly how Linnaeus' genus concept, and especially the use of parts, elements, dimensions and the states were realized in Genera Plantarum. We inspect the sixth edition (Stockholm, 1764) which, together with the fifth, serves as the starting point of the currently used nomenclature of plant genera. In Ratio operis introducing the volume (p. viii), Linnaeus lists the same 26 elements as in the first edition of Genera Plantarum (cf. footnote 1 of this paper), 13 years after he already increased their number to 31 in $\mathrm{PhB}$. Although he authored the Ratio on December 20, 1763 in Uppsala, Linnaeus did not bother with upgrading the elements of the parts, and only a short passage refers to the changes ("Partium fructificationis definitiones in Philosophia Botanica evolvantur a tyronibus", p. xv). The description of genera is quite detailed for the first six parts for the overwhelming majority of genera, whereas the receptacle appears relatively scarcely (e.g., for daisies, now: Asteraceae), as expected from plant morphology. It becomes obvious that the calyx includes only the perianthium (but also perianthium + involucrum, or perianthium + involucrum + umbella, the latter listed formerly as a kind of receptaculum) with spatha, glume, amentum and calyptra being the other states. Valva is not 
mentioned in the treatment of fungi. Of the parts of the pistil, germen has many states, especially with respect to its shape and position (but not listed in $\mathrm{PhB}$ ). As mentioned above, the elements of the pericarpium are kinds of fruit. All in all, each genus is described in terms of up to 35-40 dimensions - considerably less than what Linnaeus suggested under his small table.

\section{Evolution of $P h B$}

Finally, based on the changes outlined in this paper, we examine the interesting question of how the different versions of $\mathrm{PhB}$ evolved over time. Considering the fate of $\mathbf{L}$, we can assume with good reason that Gleditsch's corrections were directly inherited by two subsequent editions. We also know that the early Vienna editions are unchanged reprints of the first one (Hulth 1907). Sprengel's two versions are obviously related. One may be tempted to say also that the Paris 1788 and Madrid1792 editions followed London 1775 by inheriting the correct result of multiplication $(\mathbf{L}=5776)$. However, upon examining the Praefatio in Paris1788, we find that the French translation was prepared using both Vienna1770 and Berlin1780. This means that the evolution of PhB can only be represented by a network (with circles), rather than a graph theoretical tree (i.e., without circles). Moreover, C. Gómez Ortega in the Praefatio to Madrid1792 refers to Willdenow (Berlin1790), while it is obvious that the Section on fructification derives directly from either of the first four editions. 
That is, the value of 5776 has three, apparently independent origins in the evolution of $\mathrm{PhB}$, as seen in the tentative summary in Fig. 4.

\section{Concluding remarks}

Regarding his attitude towards the classification of plants at higher ranks, Linnaeus was the man of numbers. Twenty out of the 24 classes of plants were defined based on the number of stamens or their groups, and the number of pistils was the fundamental criterion for delineating the orders. ${ }^{7}$ This classification scheme was regarded as a practical one, and had been used for more than 100 years. However, Linnaeus was less fortunate with his definition of the possible number of genera in Philosophia Botanica (Stockholm1951). His list of fructification parts (Section 86) was not consistent with a small summary table in Section 167, and the sum within the table as well as the multiplication that followed were in error, both arithmetically and logically. Most reprints, editions and complete rearrangements of the contents either retained the wrong numbers, corrected only some of the problems, or even introduced new mistakes. The same is true for references to $\mathrm{PhB}$ in modern times. The only versions in which $\mathbf{L}$ ever appeared according to his original intention were Berlin1780 as edited by Gleditsch, plus a Vienna and a Geneva edition that directly followed from this edition. It is remarkable, therefore, how uncritically Linnaeus' derivation was reproduced and modified during the two and a half 
centuries that passed after the first edition. Sloppiness in many versions is obvious from the present account, which has demonstrated that inconsistencies among different Sections of PhB were often increased, rather than decreased in subsequent editions and translations. Apparently, correctness of calculation simply did not matter for most authors. A potential explanation is that the theoretical number of taxa became a less interesting issue for botanists, who were increasingly concerned with the actual (empirical) number of species and genera inhabiting particular geographic regions.

Although Gleditsch' arithmetics was correct, he overlooked the wrong number of elements of seed and receptacle in the summary table. It means that this table, in a form consistent with Section 86, and the correct derivation of $\mathbf{L}$ have never appeared together in the same publication during the past 265 years! Therefore, we take the liberty here to redo the table and the calculations according to Linnaeus' original intention and print an error-free summary (for the first time in the history of botany) as follows:

$\begin{array}{cr}\text { Sint Fructificationis partes } & \text { VII. } \\ \text { Calycis } & 7 \\ \text { Corollae } & 2 \\ \text { Staminum } & 3 \\ \text { Pistilli } & 3 \\ \text { Pericarpii } & 8 \\ \text { Seminis } & 3 \\ \text { Receptaculi } & 5 \\ \text {-------' Summa } & 31 .\end{array}$

\footnotetext{
${ }^{7}$ Linné: Systema Naturae 1735.
} 


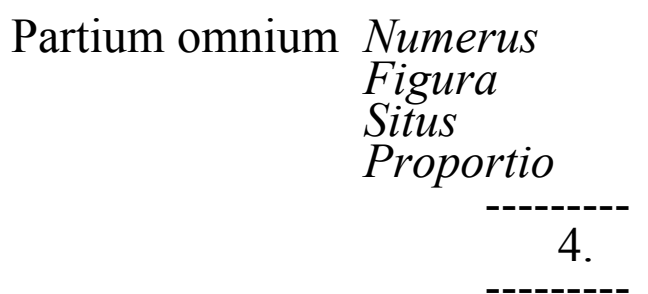

ergo quater triginta unus: 124 .

Mutetur modus secundum partes 31, sit 3844. adeoque sufficit fructificatio ad minimum generibus 3844 quae nunquam existant.

We have shown further that if $\mathbf{L}=4 n^{2}$, then any historical value, arithmetically correct or not, is many-many magnitudes lower than what elementary combinatorics suggests. It has also become clear from the overview of the Section on fructification that Linnaeus himself did not take his own claim seriously. The four dimensions so important in deriving $\mathbf{L}$ are specified for a few elements only. Elements of four parts, calyx, seed, pericarpium and receptacle are in fact kinds, for which the use of four dimensions may not have been adequate in all cases. Close inspection of Genera Plantarum demonstrates that Linnaeus used no more than 35-40 individual dimensions for the characterization of each genus. It is therefore reasonable to say that Linnaeus did not think that every genus may be described in terms of $4 n$ dimensions - he only meant that 124 is the set of all possibilities, and around one third of them are relevant only in a particular case.

Based on the corrections and also considering the Preface in reworked editions, we outlined an evolutionary network for 13 historical and 2 modern versions or 
translations of $\mathrm{PhB}$. This diagram shows most likely interactions between the editions, but we emphasize that a more thorough textual analysis is required in the future to provide a refined view on how Linnaeus' seminal work changed over time.

\section{References}

Andrietti, F. and Generali, D. 2002. Storia e storiografia della scienza: il caso della sistematica. Milano: Franco Angeli.

Atran, S. 1987. Origin of the species and genus concepts: An anthropological perspective. Journal of the History of Biology 20(2): 195-279.

Atran, S. 1990. Cognitive Foundations of Natural History. Towards an Anthropology of Science. Cambridge: Cambridge University Press.

Bueno, G. 1998. Los limites de la Evolución en el ámbito de la Scala Naturae. In: E. Molina, A. Carreras and J. Puertas (eds.), Evolucionismo y racionalismo. Zaragoza: Institución Fernando el Católico. pp. 49-88.

Cain, A. J. 1993. Linnaeus's 'Ordines Naturales. Archives of Natural History 20: 405-415.

Cain, A. J. 1994. Numerus, Figura, Proportio, Situs; Linnaeus's definitory attributes. Archives of Natural History 21: 17-36.

Čermáková, L. 2013. Úloha smyslového vnímání při poznávání a popisu př́rody $\mathrm{v}$ renesanci. (The Role of Sensory Perception in Cognition and Description of Nature in the Renaissance.) MSc thesis, Charles University, Prague. 
Eddy, M. D. 2010. Tools for reordering: Commonplacing and the space of words in Linnaeus's Philosophia Botanica. Intellectual History Review 20: 227 52.

Ereshefsky, M. 1997. The evolution of the Linnaean hierarchy. Biology and Philosophy 12: 493-519.

Ereshefsky, M. 2004. The Poverty of the Linnaean Hierarchy: A Philosophical Study of Biological Taxonomy. Cambridge: Cambridge University Press.

Foucault, M. 2002. The Order of Things: An Archaeology of Human Sciences. London: Routledge. Originally: Les mots et les choses. Paris: Gallimard. 1966.

Freer, S. 2003. Preface to Philosophia Botanica. Oxford: Oxford Univ. Press. pp. ix-xiii.

Géczy, B. 1982. Lamarck és Darwin. Budapest: Gondolat.

Hacker, J. B. 1992. To name a plant - a historical perspective. Queensland Naturalist 32: 2-13.

Hulth, J. M. 1907. Bibliographia Linnaeana. Matériaux pour servir a une bibliographie linnéenne. Partie I, Livraison I. Uppsala: Kungl. Vetenskaps Societeten.

Kwa, Chunglin. 2011. Styles of Knowing. A New History of Science from Ancient Times to the Present. Pittsburgh, PA: University of Pittsburgh Press. Originally: De ontdekking van het weten: Ein andere geschiedenis van de wetenschap. Amsterdam, 2005.

Lara Filho, D. de. 2006. Museu: de espelho do mundo a espaco relaçional. MSc thesis, Univ. Sao Paulo. 
Larson, J. L. 1971. Reason and Experience. The Representation of Natural Order in the Work of Carl von Linné. Berkeley: University of California Press. Lee, J. 1788. An introduction to the science of botany chiefly extracted from the works of Linnaeus, to which are added several new tables and notes and a life of the author. London. Printed for F.C. and J. Rivington, Wilkie and Robinson, J. Walker, White and Co.

Müller-Wille, S. 2007. Collection and collation: theory and practice of Linnaean botany. Studies in History and Philosophy of Biological and Biomedical Sciences 38: 541-562.

Müller-Wille, S and Reeds, K. 2007. A translation of Carl Linnaeus's introduction to Genera plantarum (1737). Studies in History and Philosophy of Biological and Biomedical Sciences 38: 563-572.

Müller-Ville, S. and Scharf, S. 2009. Indexing nature: Carl Linnaeus (17071778) and his fact-gathering strategies. Working Papers on The Nature of Evidence: How Well Do 'Facts' Travel? No. 36/08.

Oittinen, V. 2007. Kant ja Linné. Ajatus 64: 31-50.

Oittinen, V. 2009. Linné zwischen Wolff und Kant. Zu einigen Kantischen Motiven in Linnés biologischer Klassifikation. pp. 51-77. In: E.-O. Onnasch (ed.), Kants Philosophie der Natur, ihre Entwicklung im Opus postumum und ihre Wirkung. Berlin, New York: Walter de Gruyter.

Pulteney, R. 1805. A General View of the Writings of Linnaeus. 2nd ed. London: Mawman.

Roger, J. 1981. Linné et l'ordre de la nature. Arion 6(5-6): 3-7.

Scopoli, G. A. 1786. Fundamenta Botanica. Vienna. 
Soulsby, B. H. 1933. A catalogue of the works of Linnaeus (and publications more immediately relating thereto) preserved in the libraries of the British Museum (Bloomsbury) and the British Museum (Natural History) (South Kensington). London: British Museum.

Stafleu, F. A. 1971. Linnaeus and the Linneans: The Spreading of their Ideas in Systematic Botany, 1735-1789. Utrecht: Oosthoek.

Stafleu, F. A. and Cowan, R. S. 1981. Taxonomic Literature. A Selective Guide to Botanical Publications with dates, Commentaries and Types. Vol III: Lh-O. Regnum Vegetabile 105.

Stearn, W.T. 1985. Botanical Latin. Newton Abbot: David \& Charles.

Stemerding, D. 1991. Plants, animals and formulae: natural history in the light of Latour's Science in action and Foucault's The order of things. $\mathrm{PhD}$ thesis, University of Twente.

Svenson, H. K. 1945. On the descriptive method of Linnaeus. Rhodora 47: 273302.

Vasilyeva, L. N. and S. L. Stephenson. 2008. The Linnaean hierarchy and 'extensional thinking'. The Open Evolution Journal 2: 55-65.

Weinberger, D. 2007. Everything Is Miscellaneous: The Power of the New Digital Disorder. Times Books, New York: Henry Holt and Co.

\section{Appendix}

Here we provide a detailed estimation of $\mathbf{L}$, based on modern combinatorial thinking and on the detailed list of elements and their dimensions in PhB. First of all, the 31 elements are partitioned into 23 kinds and 8 parts, respectively, as 
shown in the main text. The number of possibilities is determined for each main part separately, considering whether their elements are parts or kinds. The operation "+" applies to kinds, and "." to parts. Then, assuming independence between the seven parts, the seven numbers are multiplied to obtain $\mathbf{L}$.

I. For part calyx, element 1 (perianthium) ${ }^{8}$ has all the four dimensions with the following number of states: numerus 3, figura 4, proportio 3 and situs 3 (Fig. 2). That is, if these states are freely combined (which is probably not plausible biologically), then we have $3 \cdot 4 \cdot 3 \cdot 3=108$ possibilities. Element 2 (involucrum) is not described in terms of the four dimensions, while its number may have 6 states (from monophyllum to hexaphyllum, p. 63). The same is true for element 4, the spatha, with three states (p. 64). No dimensions for kinds 3 and 5-7 (amentum, gluma, calyptra and valva) are mentioned at all, so we cannot do any better than counting them only once. In sum, the calyx may have $108+6+3+1+1+1+1=121$ distinct realizations.

II. For the corolla part, element 8 , the petalum is counted with 8 possible states but the other three dimensions are ignored (p. 64). Element 9 (nectarium) is described in terms of figura (with 4 states), proportio ( 2 states) and locus (2 states). For the corolla, we thus have $8 \cdot 4 \cdot 2 \cdot 2=128$ possibilities.

\footnotetext{
${ }^{8}$ Numbering of elements as in Section 86 of $\mathrm{PhB}$, Stockholm1751.
} 
III. For the stamen, element 10, the filamentum has all the four dimensions: numerus (ca. 15 states, as we know from Systema naturae), figura (8 states), proportio (4 states) and situs (4 states). Element 11, anthera, has numerus (4 states), figura (5 states) and situs (4 states). Element 12, pollen, has only one dimension, figura, with 7 states. Altogether, for stamen the number of distinct morphologies would be $15 \cdot 8 \cdot 4 \cdot 4 \cdot 4 \cdot 5 \cdot 4 \cdot 7=1,075,200$.

IV. For the last main part of the flower, the pistillum, element 13 (germen) is not detailed at all and the reader is referred to the pericarp; element 14, the stylus has numerus (we assume 4 states according to Systema naturae), figura (5 states and situs (4 states). Element 15, the stigma has numerus ( 5 states) and figura (17 states). The pistillum may therefore give rise to $4 \cdot 5 \cdot 4 \cdot 5 \cdot 17=6800$ different realizations.

V. The first fruit part, the pericarpium includes eight elements (here kinds) (16: capsula, 17: siliqua, 18: legumen, 19: conceptaculum, 20: drupa, 21: pomum, 22: bacca, 23: strobilus), and only capsula is detailed for numerus (7 states, for example, unicapsularis and multicapsularis), figura (7 states) and situs (3 states). Therefore, this part contributes to the total number of combinations by 7 $+7 \cdot 7 \cdot 3=154$ 
VI. For the semen, we have elements 24-26, the semen, the nux and the propago. Only the semen sensu stricto is detailed in terms of numerus (4 states), figura ( 5 states) and situs ( 4 states). We thus have $4 \cdot 5 \cdot 4+1+1=82$ versions. VII. The receptaculum part, containing elements 27 (receptaculum proprium), 28 (receptaculum commune), 29 (umbella), 30 (cyma) and 31 (spadix) is almost completely neglected in the discussion of $\mathrm{PhB}$, only the figura of receptaculum is mentioned with 3 possible states (p. 71). Therefore, it is counted as $1+1+1$ $+1+3=7$

If all the main parts, elements (kinds plus smaller parts), dimensions and their states may combine freely (which is impossible biologically), then these seven sums obtained above must be multiplied, giving the most conservative mathematical upper bound as $\mathbf{L}=121 \cdot 128 \cdot 1,075,200 \cdot 6800 \cdot 154 \cdot 82 \cdot 7=$ $10^{19}$ (ten quintillion) which is astronomical given that the highest estimates for the number of extant species are between $10^{7}$ and $10^{8}$. For comparison, note that the total mass of the hydrosphere of our Earth is $1.4 \cdot 10^{18}$ (1.4 quintillion) metric tons. Consequently, if we take Linnaeus' suggestion seriously, the possible number of genera is far beyond reality and, even if we forget about the impossible combinations, the outcome still remains in the realm of incomprehensibly large numbers. 
Even though in some instances the number of states and the status of the dimension we used here could be debated, the mathematically correct estimation of the potential number would probably be of similar magnitude as the above result. 
Table 1. List of various editions of Philosophia Botanica examined in this study. Initials of editors and translators follow the latinized names as published, rather than the original. For example, Curt Sprengel is better known as Kurt Polycarp Joachim Sprengel (1766-1833), and he should not be confused with Carl Sprengel (1787-1859).

\begin{tabular}{|c|c|c|c|}
\hline Year & Location & Language & Editor/translator \\
\hline 1751 & Stockholm \& Amsterdam & Latin & \\
\hline 1755 & Vienna & Latin & \\
\hline 1763 & Vienna & Latin & \\
\hline 1770 & Vienna & Latin & \\
\hline 1775 & London & English & H. Rose \\
\hline 1780 & Berlin & Latin & J. G. Gleditsch \\
\hline 1783 & Vienna & Latin & \\
\hline 1787 & Geneva & Latin & J. E. Gilibert \\
\hline 1788 & Paris \& Rouen & French & F.-A. Quesné \\
\hline 1790 & Berlin & Latin & C. L. Willdenow \\
\hline 1792 & Madrid & Latin & C. G. Ortega \\
\hline 1809 & Halle (Saale) & Latin & C. Sprengel \\
\hline 1824 & Tournay & Latin & C. Sprengel \\
\hline 1989 & Moscow & Russian & $\begin{array}{l}\text { M. E. Kirpichnikova, } \\
\text { I. E. Amlinsky, } \\
\text { N. N. Zabinkovoy, } \\
\text { S. V. Sapozhnikova }\end{array}$ \\
\hline 2003 & Oxford & English & S. Freer \\
\hline
\end{tabular}


a FRUCTIFICATIO.

\section{FR UCT IFICA TIO.}

86. FRUCTIFICATIO (79 Vegetabilium pars temporaria, Generationi dicata, antiquum terminans, novum incipiens; hujus Partes VII. numerantur:

I. CALYX, Cortex plantæ in fructificatione præfens.

1. Perianthinin, Calyx Plantæ (7\$) Frtctificationi contiguus.

a. Iructificationis, Stamina Gcrmenque includens.

b. Foris, Stamina absque Germine continens.

c. Frutus, Germen absque Staminibus continens.

2. Involacrinn f. 135. Calyx Unbellx (29) a fiore remotus,

a. Univerfale umbella univerfali fribjectum.

b. Partirle umbellulæ partiali fibjectum.

3. Amchtum f. 137. Calyx ex Receptaculo communi paleaceo gemmaceo.

4. Spatha f. 132, 133. Calyx Spadicis (31) longitudinaliter ruptus.

FRUCTIFICATIO:

92. STRUCTURAM triplicem Fructificationis, in omsibus ejusdem partibus (85), ubique obfervat Botanicus: Naturalifinsam, Differentem \& Singularem; Et has lecundum quatuor Dimin/iones: Numerum, Figuram, Proportionem \& Situm ad. tento oculo deicribat.

c 99. CALYX differt (98) quoad a Numerum, Compolitionem, Partes, Lacinias. B. Figuram, Equalitatem, Marginen, Apicem. $\gamma$. Proportionem. d. Locum, Durationem.

Ninncitus: Nullus: Tulipa, Fritillaria, Liliacei plurimi. Unicus: Primmla, Plevique flores.

Gominus: Mfalva, Hibifcus, Bixa.

Fig. 1 Snippet views from Chapter 4 of $\mathrm{PhB}$. a: Top of the first page, the beginning of Section 86. b: The starting aphorism in Section 92, c: First details on calyx in Section 99. 


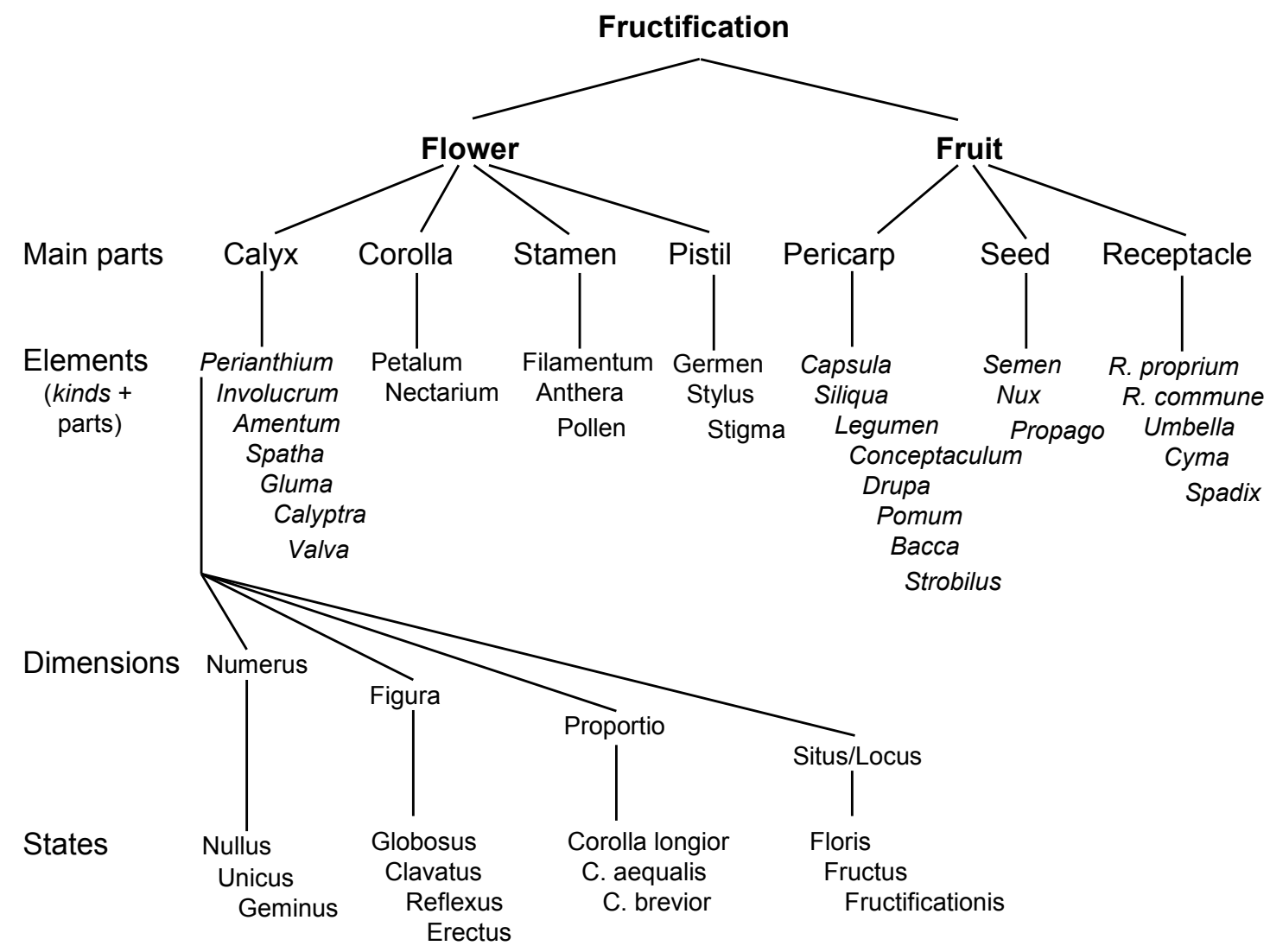

Fig 2 Character hierarchy for fructification in Philosophia Botanica. Only element 1 of main part I is detailed for the four principal dimensions and their states. Within elements, kinds are shown in italics. 
a 167. NOTA CHARACTERISTICA (189) omnis erui debet a Numero, Figura, Proportione \& ferentium $(98-104)$

Methodum, qua character omnis genericus conficiendus eft,

tralit.
Numerts non excelit 24 literas alphabeti.

Sint FruEfificationis partes VII.

Calycis

Coiollis

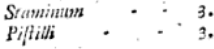

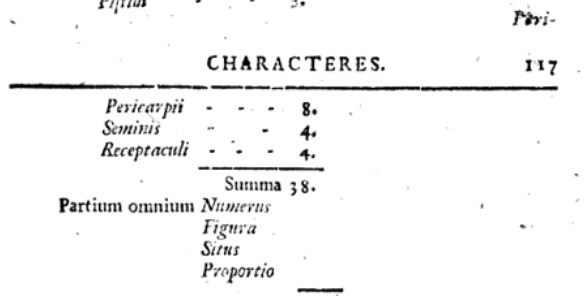

ergo quater triginta octo: $\frac{4 .}{1 \leqslant 2}$

Mutenir adeoque fufficint fructificatio ad minimum generibus 5736 ,

C

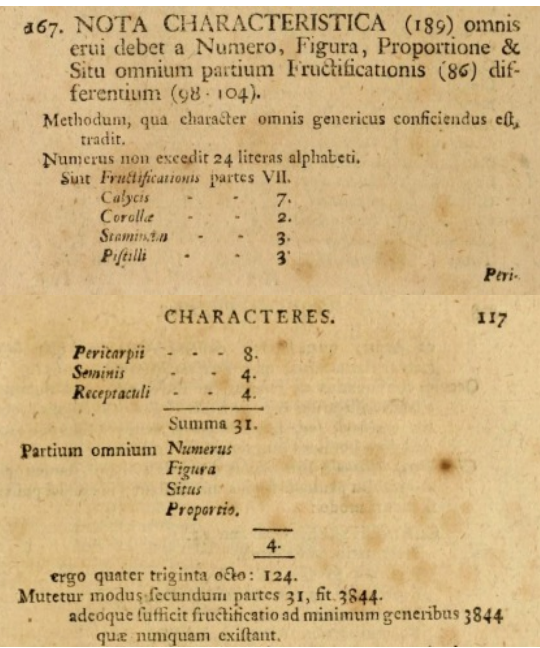

b

167. TOUTE NOTE CARACTÉRISTIQUE (189) doit être tirée du Nombre, de la Figure, de la Proportion \& de la Situation de toutes les parties différentes $(98-104)$ de la Fructification ( 86 ).

Ce qui peut contribuer a la confection de tout caracetere gónerique fournit une Methode.
Le nombre n'excede point les 24 Lettres de l'Alphabet.

Qu'on prenne VII parties de la Fruaification.

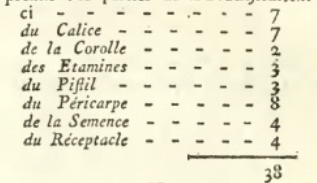

De toutes les parties $\left\{\begin{array}{l}\text { le Nombre. } \\ \text { la Figure: } \\ \text { la Situation. } \\ \text { la Proportion. }\end{array}\right\} 4$

I les parcies qui, multiplié: Par res au moins, qui n'exiftent jamais. d

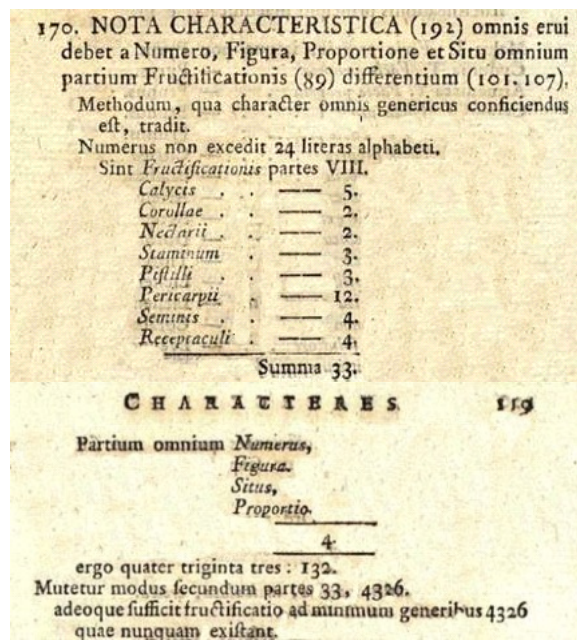

Fig 3 Snippet views from four editions of $\mathrm{PhB}$ showing the small table of the numbers of fructification parts. a: First edition (Stockholm1751, pp. 116-117), b: French translation (Paris1788, p. 152), c: Edition due to Gleditsch (Berlin1780, pp. 116-117), d: Willdenow's drastic changes (Berlin1790, pp. 118-119). 


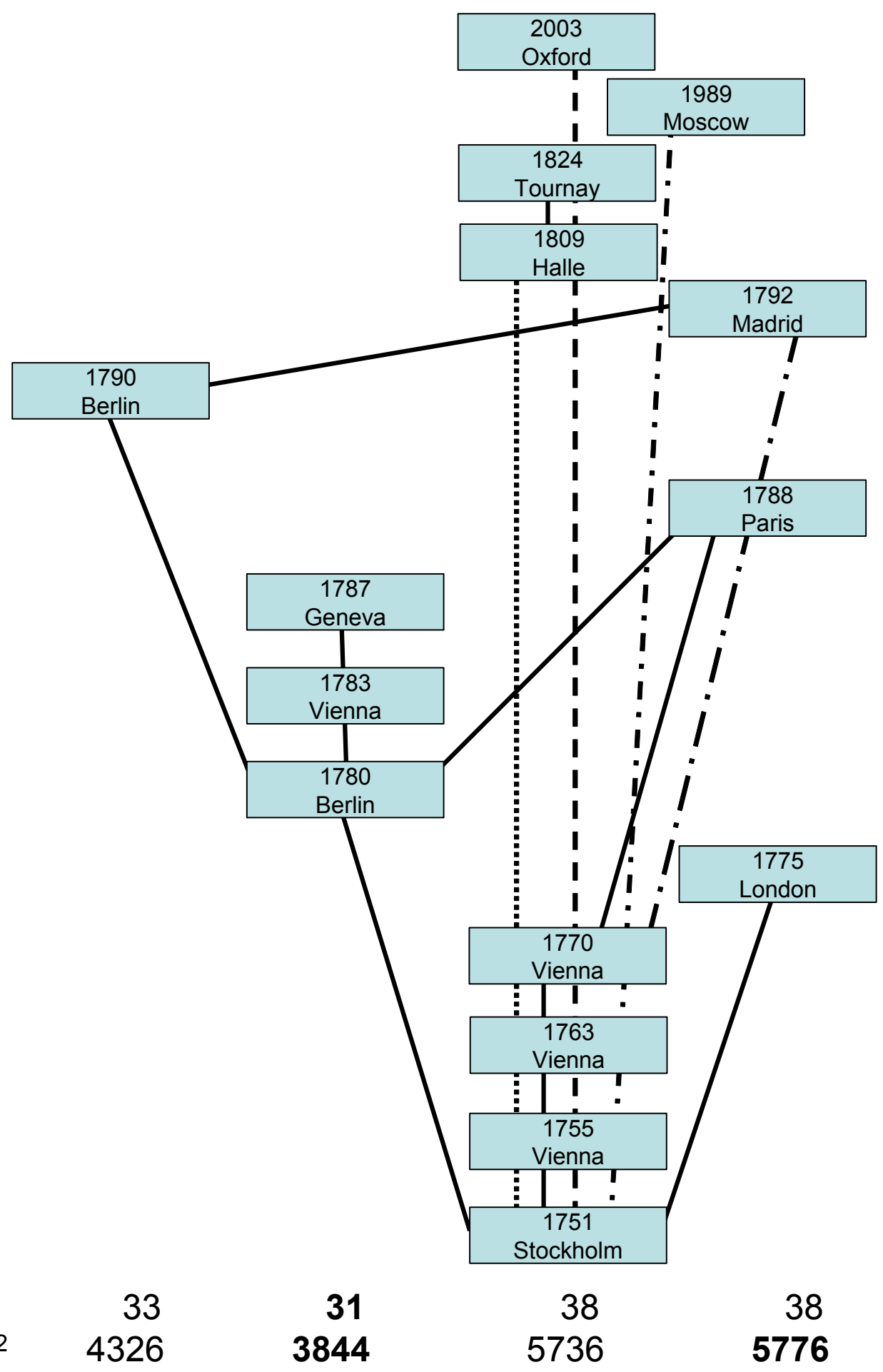

Fig 4 Evolutionary network for Philosophia Botanica embedded into a twodimensional space with $n$ and $4 n^{2}$ as horizontal axis (nominal scale) and time as vertical (ordinal scale). Arithmetically correct values from Section Nota Characteristica are in bold. Moscow1989 is in a transitional position along the horizontal axis because 5776 is given only in a comment, rather than the main text. 